\title{
PENGARUH METODE PROBLEM SOLVING TERHADAP HASIL BELAJAR IPS SISWA KELAS VIII SMP
}

\author{
Oleh \\ Ni Ketut Patri \\ SMP Negeri $2 \mathrm{Kubu}$ \\ e-mail:n_patri@yahoo.com
}

\begin{abstract}
ABSTRAK
Penelitian ini dilatarbelakangi oleh rendahnya hasil belajar IPS siswa. Penelitian ini bertujuan untuk meningkatkan hasil belajar IPS siswa dalam pembelajaran IPS dengan metode problem solving. Data dalam penelitian ini diperoleh dengan metode tes yang dilengkapi dengan instrumen berupa tes (soal) uraian. Data yang terkumpul dianalisis dengan menggunakan deskriptif statistik.Hasil pelaksanaan tindakan pada penelitian ini menunjukkan bahwapenerapanmetode problem solving dapat meningkatkan hasil belajar IPS siswa. Pada refleksi awal nilai ratarata siswa sebesar 69,85. Hasil evaluasi pada siklus I menunjukkan bahwa nilai rata-rata siswa sebesar 74,42 dengan ketuntasan klasikal 66,67\%. Pada siklus II nilai rata-rata siswa sebesar82,11 dengan ketuntasan klasikal 87,21\%. Dari hasil tersebut ada perbedaan hasil belajar siswa antara sebelum dan sesudah penerapan metode problem solving. Dengan demikian, penerapan pembelajaran dengan metode problem solving dapat meningkatkan hasil belajar IPS.
\end{abstract}

Kata kunci: Problem Solving, hasil belajar

\begin{abstract}
This research was motivated by student's low learning outcomes in Social Science. This study aims to improve the student'slearning outcomes insocial science through the application of problem solving method in learning activities. The data in this research were collected by test method which was completed with instrument in the form of descriptive test. The collected data were analyzed using descriptive statistic. The results of the study indicates that the application of problem solving method can improve student's learning outcomes of Social Science. During the initial reflection, the student's average score was 69,85. The results of evaluation in cycle I showed that the average score of students was 74,42 and the classical learning completeness was 66,67\%, in the second cycle the average score of students was 82,11 and the classicallearning completeness was $87,21 \%$. From these results, there were differences in student's learning outcomes between before and after the application of problem solving learning method. Hence, problem solving learning method can improve the learning result of Social Science.
\end{abstract}

Keywords: Problem Solving, learning outcomes 


\section{PENDAHULAN}

Pendidikan memegang peranan penting untuk menjamin kelangsungan hidup dalam kehidupan yang serba maju, modern, dan serba canggih seperti saat ini. Pendidikan merupakan wahana untuk meningkatkan dan mengembangkan kualitas sumber daya manusia. Melalui penyelenggaraan pendidikan diharapkan dapat tercetak generasi berkualitas yang akan mendukung tercapainya sasaran pembangunan nasional. Dalam Pasal 20 UU Tahun 2003, pendidikan nasional berfungsi untuk mengembangkan kemampuan dan membentuk watak serta peradaban bangsa dengan tujuan untuk mengembangkan potensi yang dimiliki peserta didik agar menjadi manusia yang berkualitas dengan ciri-ciri beriman dan bertaqwa kepada Tuhan YME, berakhlak mulia, sehat, beriman, cakap, kreatif, mandiri, dan menjadi warga negara yang demokratis, serta bertanggung jawab (UU no 20 tahun 2003).Kini semakin disadari bahwa pendidikan memainkan peranan yang sangat penting dalam kehidupan dan kemajuan umat manusia. Pendidikan merupakan suatu kekuatan yang dinamis dalam kehidupan setiap individu, yang mempengaruhi perkembangan fisiknya, daya, jiwa, sosial, dan moralitasnya, atau dengan perkataan lain, pendidikan merupakan suatu kekuatan yang dinamis dalam mempengaruhi kemampuan, kepribadian, dan kehidupan individu dalam pertemuan dan pergaulannya dengan sesama, serta hubungannya dengan Tuhan. Pendidikan adalah usaha sadar untuk menyiapkan peserta didik melalui kegiatan-kegiatan bimbingan, pengajaran, dan atau latihan bagi peranannya di masa yang akan datang.Mutu pendidikan sangat erat hubungannya dengan mutu siswa, karena siswa merupakan titik pusat pembelajaran. Oleh karena itu, dalam meningkatkan mutu pendidikan harus diikuti dengan peningkatan mutu siswa. Peningkatan mutu siswa dapat dilihat pada tingginya tingkat hasil belajar siswa, sedangkan tingginya tingkat hasil belajar siswa dipengaruhi oleh besarnya minat belajar siswa itu sendiri.

Pembelajaran IPS di SMP Negeri 2 Kubu berdasarkan data observasi awal bahwa sebagian besar siswa belum memiliki semangat dan minat untuk belajar IPS secara optimal. Data yang diperoleh dari observasi awal yaitu rata-rata hasil belajar IPSsiswa hanya mencapai 69,85. Semangat dan minat siswa dalam 
melaksanakan tugas guru, daya tangkap siswa dalam menerima pelajaran, kemampuan siswa dalam menghubungkan materi pelajaran dengan dunia nyata, kemampuan siswa dalam belajar mandiri, kemampuan siswa dalam menuliskan ide, kemampuan siswa dalam mengerjakan tugas mandiri, keberanian siswa dalam menyajikan temuan, keterampilan siswa menulis di papan tulis, dirasa masih rendah dan belum sesuai dengan kompetensi yang diharapkan.Keadaan ini memotivasiguru untuk lebih kreatif memilih metode pembelajaran yang sesuai untuk materi pelajaran yang akan disajikan kepada siswa. Dalam proses pembelajaran IPS selama ini dengan keadaan siswa yang ada, umumnya guru lebih berperan aktif dengan pengajaran dalam bentuk informasi, contoh soal, dan soal latihan, sedangkan siswa kecendrungannya duduk, mendengar, mencatat, menghafal, dan bekerja secara individu di tempat duduknya masing-masing. Padahal, Kurikulum menuntut agar dalam pelaksanaan kegiatan pembelajaran, guru hendaknya memilih dan menggunakan metode yang melibatkan siswa aktif dalam belajar, baik secara mental, fisik, maupun sosial, dan dalam mengaktifkan siswa.

Masih rendahnya hasil belajar IPS disebabkan oleh masih dominannya kegiatan menghafal daripada memproses sendiri pemahaman suatu materi. Sikap siswa selama mengikuti proses pembelajaran tidak fokus dan ramai sendiri. Hal ini dipengaruhi oleh metode mengajar yang digunakan guru dalam menyampaikan materi. Metode yang konvensional seperti menjelaskan materi secara abstrak, hafalan materi, dan ceramah dengan komunikasi satu arah, yang aktif masih didominasi oleh pengajar, sedangkan siswa biasanya hanya memfokuskan penglihatan dan pendengaran. Kondisi pembelajaran seperti inilah yang mengakibatkan siswa kurang aktif dan pembelajaran yang dilakukan kurang efektif. Disini guru dituntut untuk pandai menciptakan suasana pembelajaran yang menyenangkan bagi siswa sehingga siswa kembali berminat mengikuti kegiatan belajar.

Setiap proses pembelajaran ditandai dengan adanya beberapa unsur, antara lain: tujuan, bahan, alat, metode, dan evaluasi. Unsur metode dan alat merupakan unsur yang tidak bisa dilepaskan dari unsur lainnya yang berfungsi sebagai cara 
atau teknik untuk mengantarkan bahan pelajaran agar sampai kepada tujuan. Dalam pencapaian tujuan tersebut, metode pembelajaran sangat penting sebab dengan adanya metode pembelajaran yang tepat, materi dapat dengan mudah dipahami oleh siswa.

Berdasarkan uraian di atas, salah satu alternatif yang dapat ditempuh untuk mengatasi permasalahan tersebut adalah dengan cara melaksanakan pembelajaran yang inovatif pada mata pelajaran IPS. Salah satu pembelajaran inovatif yang dapat diterapkan sesuai dengan masalah yang dihadapi siswa adalah penerapan pembelajaran dengan metode problem solving.

Pembelajaran adalah suatu kegiatan agar proses belajar seseorang atau sekelompok orang yang berkaitan dengan suatu usaha untuk mencapai tujuan yang telah ditetapkan. Untuk mencapai tujuan tersebut, di dalam proses pembelajaran terdapat beberapa komponen penting, yakni guru, media belajar, metode belajar, kurikulum, dan lingkungan belajar.Ini akan mempengaruhi cara guru dalam menyampaikan pelajaran, yakni dengan menggunakan metode yang cocok. Peran metode pembelajaran yang digunakan yakni problem solving agar proses pembelajaran dapat berjalan dengan lancar dan efektif.Pembelajaran dikatakan efektif apabila para siswa dapat memaknai pesan yang disampaikan oleh guru. Metode problem solving dapat mengajarkan siswa bagaimana cara menghadapi dan memecahkan suatu permasalahan sehingga didapat jalan keluarnya.Disini siswa dilatih untuk berfikir dan memberikan pandangan secara luas dengan cara memecahkan suatu permasalahan. Dengan cara demikian diharapkan dapat dingkatkan hasil belajar siswa. Ilmu Pengetahuan Sosial merupakan program pendidikan yang berupaya mengembangkan pemahaman siswa tentang bagaimana manusia sebagai individu dan kelompok hidup bersama dan berinteraksi dengan lingkungannya, baik fisik maupun sosial. Pembelajaran Ilmu Pendidikan Sosial ataupun pengetahuan sosial bertujuan agar siswa mampu mengembangkan pengetahuan, sikap, dan keterampilan sosial, yang berguna bagi kemajuan dirinya sebagai individu maupun sebagai anggota masyarakat (Saidihardjo, 2005: 109). 
Metode problem solving atau sering juga disebut dengan nama Metode Pemecahan Masalah merupakan suatu cara mengajar yang merangsang seseorang untuk menganalisis dan melakukan sintesa dalam kesatuan struktur atau situasi di mana masalah itu berada, atas inisiatif sendiri. Metode ini menuntut kemampuan untuk dapat melihat sebab akibat atau relasi-relasi diantara berbagai data, sehingga pada akhirnya dapat menemukan kunci pembuka masalahnya. Kegiatan semacam ini merupakan ciri yang khas daripada suatu kegiatan inteligensi. Metode ini mengembangkan kemampuan berpikir yang dipupuk dengan adanya kesempatan untuk mengobservasi problema, mengumpulkan data, menganalisis data, menyusun suatu hipotesis, mencari hubungan (data) yang hilang dari data yang telah terkumpul untuk kemudian menarik kesimpulan yang merupakan hasil pemecahan masalah tersebut. Cara berpikir semacam itu lazim disebut cara berpikir ilmiah. Cara berpikir yang menghasilkan suatu kesimpulan atau keputusan yang diyakini kebenarannya karena seluruh proses pemecahan masalah itu telah diikuti dan dikontrol dari data yang pertama yang berhasil dikumpulkan dan dianalisis sampai kepada kesimpulan yang ditarik atau ditetapkan. Cara berpikir semacam itu benar-benar dapat dikembangkan dengan menggunakan Metode Pemecahan Masalah (Jusuf Djajadisastra, 1982: 19- 20).Metode problem solving melatih siswa mencari informasi dan mengecek silang validitas informasi itu dengan sumber lainnya, melatih siswa berpikir kritis, dan melatih siswa memecahkan dilema (Omi Kartawidjaya, 1988:42).Untuk mendukung strategi belajar mengajar dengan menggunakan metode problem solving ini, guru perlu memilih bahan pelajaran yang memiliki permasalahan. Materi pelajaran tidak terbatas hanya pada buku teks di sekolah, tetapi juga diambil dari sumber-sumber lingkungan, seperti peristiwa-peristiwa kemasyarakatan atau peristiwa dalam lingkungan sekolah (Gulo, 2002:114). Metode problem solving yang dilaksanakan dalam bentuk kelompok, berlangsung suatu diskusi atau pemecahan masalah bersama. Langkah- langkah metode ini adalah: (a) adanya masalah yang jelas untuk dipecahkan, (b) mencari data atau keterangan yang dapat digunakan untuk memecahkan masalah tersebut, (c) menetapkan jawaban sementara dari masalah 
tersebut, (d) menguji kebenaran jawaban sementara tersebut, dan (e) menarik kesimpulan (Nana Sudjana, 1989: 85-86).

Penilaian adalah proses memberikan atau menentukan nilai kepada objek tertentu berdasarkan suatu kriteria tertentu. Proses pemberian nilai tersebut berlangsung dalam bentuk interpretasi yang diakhiri dengan judgment. Interpretasi dan judgment merupakan tema penilaian yang mengimplikasikan adanya suatu perbandingan antara kriteria dan kenyataan dalam konteks situasi tertentu. Atas dasar itu, maka dalam kegiatan penilaian selalu ada objek/program, ada kriteria, dan ada interpretasi/judgment. Penilaian hasil belajar adalah proses pemberian nilai terhadap hasil-hasil belajar yang dicapai siswa dengan kriteria tertentu. Hal ini mengisyaratkan bahwa objek yang dinilainya adalah hasil belajar siswa. Hasil belajar siswa pada hakikatnya adalah perubahan tingkah laku. Tingkah laku sebagai hasil belajar dalam pengertian yang luas mencakup bidang kognitif, afektif, dan psikomotor. Oleh sebab itu, dalam penilaian hasil belajar, peranan tujuan instruksional yang berisi rumusan kemampuan dan tingkah laku yang diinginkan dikuasai siswa menjadi unsur penting sebagai dasar dan acuan penilaian. Penilaian proses belajar adalah upaya memberi nilai terhadap kegiatan pembelajaran yang dilakukan oleh siswa dan guru dalam mencapai tujuan-tujuan pengajaran (Nana Sudjana, 2005: 3).

Hasil belajar merupakan segala upaya yang menyangkut aktivitas otak (proses berpikir) terutama dalam ranah kognitif, afektif, dan psikomotorik. Proses berpikir ini ada enam jenjang, mulai dari yang terendah sampai dengan jenjang tertinggi (Suharsimi Arikunto, 2003: 114-115). Keenam jenjang tersebut adalah: (1) Pengetahuan (knowledge) yaitu kemampuan seseorang untuk mengingat kembali tentang nama, istilah, ide, gejala, rumus-rumus dan lain sebagainya, tanpa mengharapkan kemampuan untuk menggunakannya. (2) Pemahaman (comprehension) yakni kemampuan seseorang untuk memahami sesuatu setelah sesuatu itu diketahui dan diingat melalui penjelasan dari kata- katanya sendiri. (3) Penerapan (application) yaitu kesanggupan seseorang untuk menggunakan ide-ide umum, tata cara atau metode-metode, prinsip-prinsip, rumus-rumus, teori-teori, dan lain sebagainya dalam situasi yang baru dan konkret. (4) Analisis (analysis) 
yakni kemampuan seseorang untuk menguraikan suatu bahan atau keadaan menurut bagian-bagian yang lebih kecil dan mampu memahami hubungan diantara bagian-bagian tersebut. (5) Sintesis (synthesis) adalah kemampuan berpikir memadukan bagian-bagian atau unsur-unsur secara logis, sehingga menjadi suatu pola yang baru dan terstruktur. (6) Evaluasi (evaluation) yang merupakan jenjang berpikir paling tinggi dalam ranah kognitif menurut Taksonomi Bloom. Penelitian disini adalah kemampuan seseorang untuk membuat pertimbangan terhadap suatu situasi, nilai atau ide, atas beberapa pilihan kemudian menentukan pilihan nilai atau ide yang tepat sesuai dengan kriteria yang ada (Anas Sudijono, 2005: 50- 52).Pada pendidikan formal, semua bidang studi dan bidang pendidikan harus memanfaatkan dasar mental yang ada pada tiap anak untuk meningkatkan kemampuan mentalnya kearah kematangan dan kedewasaan dalam arti seluas-luasnya. Oleh karena itu, penyelenggara pendidikan dan pengajaran harus dilaksakan secara teratur, terarah, dan terencana sesuai dengan pengembangan dasar dan kemampuan mental anak, agar tujuan pendidikan dan pengajaran tercapai secara maksimal (Nursid Sumaatmadja, 2001: 2). Dalam kegiatan belajar mengajar setiap guru selalu berusaha melakukan kegiatan pembelajaran secara efektif dan efisien dalam mencapai tujuan pembelajaran. Kegiatan pembelajaran secara efektif disini dimaksudkan agar pembelajaran tersebut dapat membawa hasil atau berhasil guna, dan kegiatan pembelajaran secara efisien dimaksudkan agar pembelajaran tersebut dapat berdaya guna atau tepat guna baik di lingkungan sekolah maupun dalam kehidupan bermasyarakat.

Menurut Nana Sudjana (2005: 3) hakikat hasil belajar adalah perubahan tingkah laku individu yang mencakup aspek kognitif, afektif, dan psikomotorik. Menurut Nana Sudjana (1989: 38-40) hasil belajar yang dicapai siswa dipengaruhi oleh dua faktor utama, yakni faktor dari dalam diri siswa itu dan faktor yang datang dari luar diri siswa atau faktor lingkungan. Faktor yang datang dari diri siswa terutama kemampuan yang dimilikinya. Faktor kemampuan siswa besar sekali pengaruhnya terhadap hasil belajar yang dicapai. Disamping faktor kemampuan yang dimiliki siswa, juga ada faktor lain, seperti motivasi belajar, 
minat dan perhatian, sikap dan kebiasaan belajar, ketekunan, sosial ekonomi, faktor fisik dan psikis.Salah satu upaya mengukur hasil belajar siswa dilihat dari hasil belajar siswa itu sendiri. Bukti dari usaha yang dilakukan dalam proses belajar adalah hasil belajar yang diukur melalui tes. Hal ini sesuai dengan yang dikemukakan oleh Ahmadi (1984:35) dalam Dimyati dan Mudjiono (2006:4) bahwa "Hasil belajar adalah hasil yang dicapai dalam suatu usaha, dalam hal ini usaha belajar dalam perwujudan prestasi belajar siswa yang dilihat pada setiap mengikuti tes". Hasil belajar dalam penelitian ini diperoleh melalui tes yang diberikan pada setiap akhir siklus.

Adapun tujuan penelitian ini adalah untuk meningkatkan hasil belajar IPS siswa kelas VIII melalui penerapan metode pembelajaran problem solving.

\section{METODE}

Penelitian ini adalah penelitian tindakan kelas (PTK) atau yang biasa disebut Classroom Action Research (CAR) yang bertujuan untuk mengadakan perbaikan dan meningkatkan proses pembelajaran. Menurut Stephen Kemmis (Hopkins. 2011:58) action research adalah: a from of self-reflektif inquiry undertaken by participants in a social (including education) situation in order to improve the rationality and of (a) their own social or educational practices justice (b) their understanding of these practices, and (c) the situastions in which practices are carried out.PTKadalahsuatubentukkajian yang bersifat reflektif oleh pelaku tindakan, yang dilakukan untuk meningkatkan kemampuan rasional dan tindakan-tindakan mereka dalam melaksanakan tugas, memperdalam pemahaman terhadap tindakan-tindakan yang dilakukannya itu, serta memperbaiki kondisi praktik-praktik pembelajaran tersebut dilakukan.

Menurut Suharsimi (2008:2), dikarenakan ada tiga kata yang membentuk pengertian PTK maka ada tiga pengertian yang dapat diterangkan (a) Penelitian menunjuk pada suatu kegiatan mencermati suatu objek dengan menggunakan cara dan aturan metodologi tertentu untuk memperoleh data atau informasi yang bermanfaat dalam meningkatkan mutu suatuhalyangmenarikminatdan penting bagipeneliti, (b) Tindakan menunjuk pada sesuatu gerak kegiatan yang sengaja 
dilakukan dengan tujuan tertentu. Dalam penelitian berbentuk rangkaian siklus kegiatan untuk siswa, (c) Kelas dalam hal ini tidak terikat pada pengertian ruang kelas, tetapi dalam pengertian yang lebih spesifik. Seperti yang sudah lama dikenal dalam bidang pendidikan dan pengajaran, yang dimaksud dengan istilah kelas adalah sekelompok siswa yang dalam waktu yang sama, menerima pelajaran yang sama dari guru yang sama pula. Secara singkat PTK dapat didefinisikan sebagai sebuah bentuk penelaahan penelitian yang bersifat reflektif dengan melakukan tindakan-tindakan tertentu agar dapat memperbaiki dan atau meningkatkan praktik-praktik pembelajaran dikelas secara profesional. Dengan demikian, penelitian ini akan dilaksanakan dalam mata pelajaran IPS dengan tujuan untuk meningkatkan hasil belajar siswa.

Populasi dalam penelitian ini adalah siswa kelas VIII SMP Negeri 2 Kubu.Subjek dalam penelitian ini adalah siswa kelas VIII A SMP Negeri 2 Kubu, yang berjumlah 39 orang. Siswa tersebut dipilih sebagai subjek penelitian karena hasil belajar IPS siswa rata-rata belum memenuhi standar ketuntasan atau kriteria ketuntasan minimal (KKM) yakni 73. Sementara itu, objek dalam penelitian ini adalah hasil belajar IPS siswa kelas VIII ASMP Negeri 2 Kubu. Variabel penelitian terdiri atas variabel bebas dan variabel terikat. Variabel bebas yaitu metode pembelajaranproblem solving. Variabel terikat yaitu hasil belajar.

Prosedur penelitian yang dilakukan meliputi (1) refleksi awal, peneliti mengkaji masalah-masalah yang dihadapi oleh siswa kelas VIII A dalam pembelajaran IPS; (2) rencana tindakan; (3) Pelaksanaan tindakan; (4) Observasi; (5) Evaluasi untuk mengetahui keberhasilan siswa dalam pembelajaran IPS dengan cara memberikan tes uraian yang terdiri atas lima butir soal; (6) Refleksi dilaksanakan setelah tindakan selesai.Data hasil belajar siswa sebelum diberikan tindakan dengan proses pembelajaran tanpa menerapkan metode problem solving tahun pelajaran sebelumnya yaitu tahun pelajaran 2016/2017 dicatat dan akan digunakan sebagai perbandingan dengan data hasil belajar siswa setelah diberikan tindakan pada siklus I dan II, sehingga nantinya akan didapatkan apakah ada peningkatan hasil belajar. Kemudian data hasil belajar siswa setelah diberikan tindakan pada masing-masing siklus dikumpulkan dengan teknik post-test setelah 
akhir tindakan. Instrumen test yang digunakan adalah tes hasil belajar berbentuk uraian.Siswa dikatakan tuntas dalam menguasai materi apabila nilai yang diperoleh minimal 73 (sesuai dengan Kriteria Ketuntasan Minimal). Secara klasikal, pembelajaran dikatakan tuntas apabila minimal $85 \%$ dari jumlah siswa yang ada di kelas itu memperoleh nilai minimal 73, sehingga tindakan bisa dihentikan. Sebaliknya, jika jumlah siswa yang memperoleh nilai minimal 73 kurang dari $85 \%$, tindakan perlu diulang sampai diperoleh nilai yang diharapkan.

Rumus untuk mengetahui persentase siswa yang sudah mencapai ketuntasan belajar (KB) adalah dengan cara membagi jumlah siswa yang memeroleh nilai minimal 73 dengan jumlah seluruh siswa, kemudian dikalikan $100 \%$. Rumusnya adalah sebagai berikut.

$$
\begin{aligned}
& X=\frac{\text { Jumlah jawabanbenar }}{\text { Jumlah seluruh soal }} \times 100 \\
& X=\frac{\sum N}{N} \times 100
\end{aligned}
$$

Keterangan:

$$
\begin{aligned}
& \sum_{\mathrm{X}} \mathrm{X}=\text { rata-rata } \\
&=\text { jumlah nilai seluruh siswa } \\
& X=\frac{\sum T}{N} \times 100 \%
\end{aligned}
$$

Keterangan:

KK = Ketuntasan Belajar Klasikal

$\sum \mathrm{T}=$ Jumlah siswa tuntas

$\mathrm{N} \quad=$ Jumlah siswa

Trianto (2010:241)

\section{HASIL DAN PEMBAHASAN}

Hasil dan pembahasan dijabarkan dalam dua bagian terpisah sebagai berikut. Hasil

Data hasil belajar siswa pada siklus I adalah sebagai berikut. 


$$
\begin{aligned}
& \bar{X}=\frac{2828}{39} \\
& \bar{X}=74,42 \quad \text { (sudah memenuhi target 73) }
\end{aligned}
$$

Ketuntasan klasikal $=\frac{26}{39} \times 100 \%$

$=66,67 \%$ (belum memenuhi target $85 \%$ )

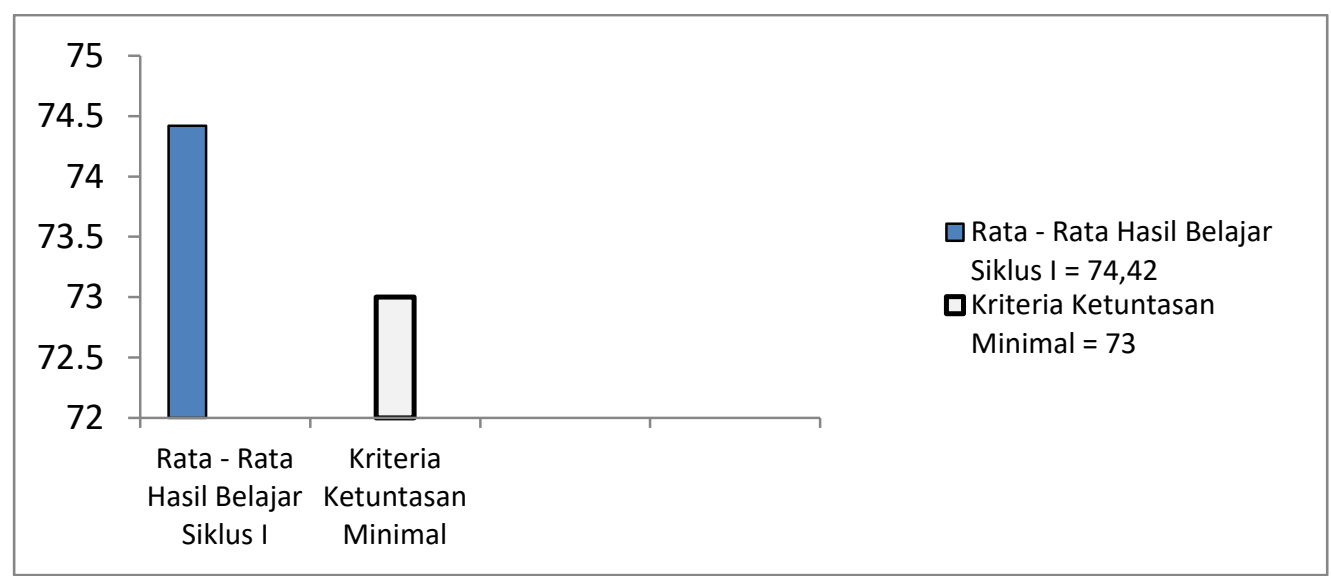

Gambar 1 Grafik Hasil Belajar Siklus I

Data hasil belajar siswa pada siklus II diperoleh rata-rata hasil belajar siswa pada siklus II yaitu :

$$
\begin{aligned}
& \bar{X}=\frac{3120}{39} \\
& \bar{X}=82,11
\end{aligned}
$$

(sudah memenuhi target 73)

$$
\begin{aligned}
\text { Ketuntasan klasikal } & =\frac{34}{39} \times 100 \% \\
& =87,21 \% \text { (sudah memenuhi target } 85 \% \text { ) }
\end{aligned}
$$

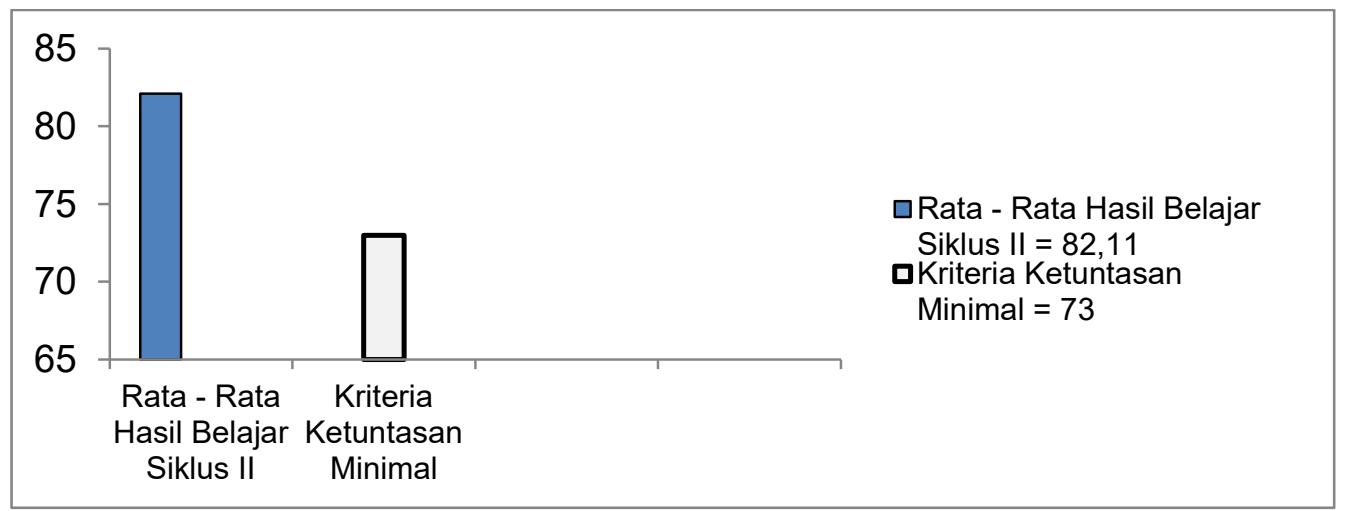

Gambar 2 Grafik Hasil Belajar Siklus II 
Kriteria Ketuntasan Minimal (KKM) pada mata pelajaran IPS adalah 73, sedangkan ketuntasan belajar klasikal pada observasi awal adalah 69,17\% dan pada siklus I 66,67\% dari jumlah siswa kelas VIII A SMP Negeri 2 Kubu yakni memperoleh nilai $73 \mathrm{ke}$ atas dengan nilai rata-rata hasil belajar 74,42 . Oleh karena itu, hasil observasi tersebut menunjukkan bahwa rata-rata hasil belajar siswa memenuhi KKM mata pelajaran.Namun,secara klasikal siswa kelas VIII A SMP Negeri 2 Kubu belum memenuhi persentase ketuntasan klasikal yang ditargetkan yaitu $85 \%$. Pada siklus II nilai rata-rata mencapai 82,11 dan ketuntasan belajar $87,21 \%$ dari jumlah siswa kelas VIII A SMP Negeri 2 Kubu. Ketuntasan belajar pada siklus II menunjukkan bahwa secara klasikal sudah memenuhi KKM yang ditargetkan. Secara lebih lengkap perbandingan hasil belajar siswa pada observasi awal, siklus I, dan siklus II dapat dilihat pada tabel berikut.?

\section{Pembahasan}

Berdasarkan analisis tes pada siklus I dan tes siklus II, dapat dilihat bahwa pembelajaran IPS dengan metode problem solving dapat meningkatkan hasil belajar IPS siswa. Dari penyajian hasil penelitian diperoleh rata-rata hasil belajar siswa setelah diberikan tindakanpada siklus I adalah 74,42 dan rata-rata hasil belajar siswa setelah diberikan tindakanpada siklus II adalah 82,11. Artinya, hasil belajar siswa pada siklus II ada peningkatan sebesar 7,69 (10,33\%)dari siklus I.

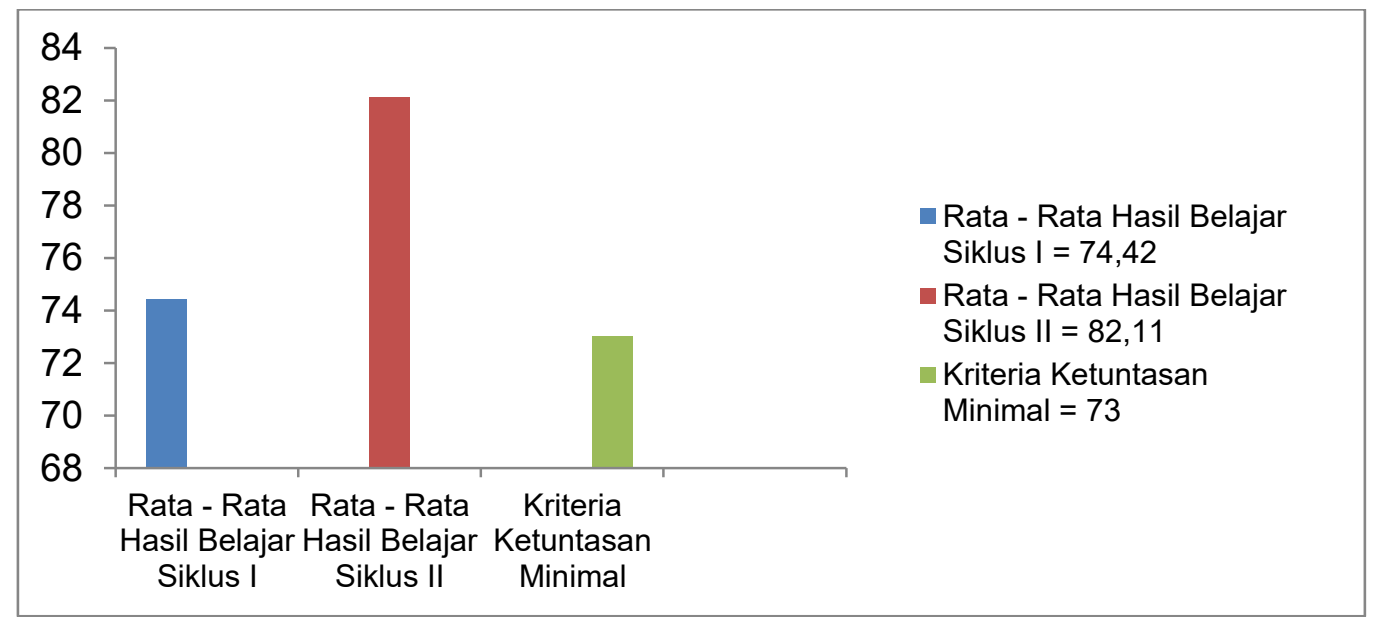

Gambar 3 Grafik Perbandingan Hasil Belajar Siklus I dan Siklus II 
Sementara itu, jika dilihat dari ketuntasan belajar klasikal siswa kelas VIII A SMP Negeri 2 Kubu juga mengalami peningkatan dari siklus I ke siklus II. Ketuntasan klasikal belajar siswa kelas VIII A SMP Negeri 2 Kubu pada siklus I adalah $66,67 \%$. Sementara itu, pada siklus II ketuntasan klasikal belajar siswa kelas VIII A SMP Negeri 2 Kubu adalah87,21\%. Hal itu menunjukkan bahwa terjadi peningkatan ketuntasan klasikal belajar siswa dari siklus I ke siklus II.

Perbandingan hasil belajar belajar siswa sebelum dan sesudah diberikan tindakan :

Rata-rata hasil belajar siswa setelah diberikan tindakan pada siklus I dan siklus II :

$\underline{X}=\frac{74,42+82,11}{2}$

$\underline{X}=\frac{156,53}{2}$

$\underline{X}=78,625$

Artinya hasil belajar siswa setelah diberikan tindakan dengan sebelum diberikan meningkat sebesar $(78,625-69,850)=8,415(12,047 \%)$

\begin{tabular}{|c|c|c|c|c|}
\hline $\begin{array}{l}80 \\
78 \\
76 \\
74 \\
72 \\
70 \\
68 \\
66 \\
64\end{array}$ & $\begin{array}{c}0 \\
3 \\
0 \\
4 \\
2 \\
2 \\
0 \\
3 \\
0 \\
4 \\
\text { Rata - Rata } \\
\text { Hasil Belajar } \\
\text { Siklus I dan } \\
\text { Siklus II }\end{array}$ & $\begin{array}{c}\text { Rata - Rata } \\
\text { Hasil Belajar } \\
\text { Sebelum } \\
\text { Diberikan } \\
\text { Tindakan } \\
\text { (Tahun } \\
\text { Pelajaran } \\
\text { 2016/2017) }\end{array}$ & $\begin{array}{c}\text { Kriteria } \\
\text { Ketuntasan } \\
\text { Minimal }\end{array}$ & $\begin{array}{l}\text { Rata - Rata Hasil Belajar } \\
\text { Siklus I dan Siklus II = } \\
78,625 \\
\text { Rata - Rata Hasil Belajar } \\
\text { Sebelum Diberikan } \\
\text { Tindakan (Tahun Pelajaran } \\
\text { 2016/2017) = 69,850 } \\
\text { Kriteria Ketuntasan Minimal } \\
=73\end{array}$ \\
\hline
\end{tabular}

Gambar 4 Grafik Perbandingan Hasil Belajar Setelah Diberikan Tindakan dan Sebelum Diberikan Tindakan

Tabel 1 Hasil Belajar Siswa pada Refleksi Awal, Siklus I, dan Siklus II 


\begin{tabular}{lll}
\hline \multicolumn{1}{c}{ Tindakan } & Nilai rata-rata & Ketuntasan belajar \\
\hline Observasi awal & 69,85 & $69,17 \%$ \\
Siklus I & 74,42 & $66,67 \%$ \\
Siklus II & 82,11 & $87,21 \%$ \\
\hline
\end{tabular}

Peningkatan nilai rata-rata dan ketuntasan klasikal belajar siswa tersebut terjadi karena pelaksanaan tindakan pada siklus II lebih dioptimalkan melalui berbagai upaya. Diskusi pada kelompok menyebabkan aktivitas dan interaksi diantara siswa untuk saling memotivasi dan saling membantu dalam menguasai materi pelajaran sehingga siswa yang lambat berpikir dapat dibantu dalam memahami materi pelajaran atau menambah ilmu pengetahuan. Di samping hal tersebut, pemberian umpan balik dan penghargaan juga berdampak positif terhadap hasil belajar siswa kelas VIII A SMP Negeri 2 Kubu. Melalui pemberian umpan balik tersebut, siswa dapat memantapkan pemahamannya terhadap materi yang dipelajari bersama kelompok kooperatif. Pemberian penghargaan dapat memotivasi siswa untuk mencapai hasil belajar yang lebih tinggi.

\section{SIMPULAN DAN SARAN}

Berdasarkan hasil penelitian dan pembahasan yang telah diuraikan pada bab sebelumnya, maka dapat disimpulkan penerapan metode problem solving pada siswa kelas VIIIA SMP Negeri 2 Kubu tahun pelajaran 2017/2018 dapat meningkatkan hasil belajar siswa sebesar 8,415 (12,047\%).

Berdasarkan simpulan, beberapa saran yang dapat disampaikan adalah sebagai berikut.Pertama para siswa diharapkan belajar secara optimal dan melibatkan diri secara aktif dalam kegiatan pembelajaran agar hasil pembelajaran pun menjadi memuaskan. Salah satunya melalui belajar bersama kelompok dengan metode problem solving. Kedua guru IPAhendaknya tetap mengupayakan penerapan berbagai metode pembelajaran yang bervariasi agar kegiatan pembelajaran lebih menyenangkan bagi siswa.Ketiga kepala Sekolah diharapkan mengupayakan pengadaan berbagai sarana yang mendukung efektivitas dan efesiensi kegiatan pembelajaran yang berlangsung di sekolah yang 
bersangkutan. Keempat peneliti lain diharapkan mengadakan penelitian lanjutan terkait dengan penerapan berbagai metode pembelajaran yang dapat diterapkan di kelas dan materi yang berbeda dari penelitian yang telah dilakukan ini. Kelima Bagi pengembang Kurikulum, diharapkan penelitian ini dapat dipakai sebagai salah satu dasar pemikiran untuk merumuskan metode pembelajaran IPS.

\section{UCAPAN TERIMAKASIH}

Ucapan terimakasih yang sebesar-besarnya ditujukan kepada (1) Drs. I Nengah Suda, M.Pd.H selaku kepala sekolah dan (2) rekan guru yang telah memberikan dukungan dan motivasi kepada penulis

\section{DAFTAR RUJUKAN}

Arikunto, Suharsimi, 2003. Dasar-Dasar Evaluasi Pendidikan. Jakarta: PT Bumi Aksara.

Arikunto, Suharsimi, 2008. Evaluasi Program Pendidikan (Edisi 2). Jakarta: PT Bumi Aksara.

BSNP. 2006. Permendiknas RI No. 22 Tahun 2006 Tentang Standar Isi untuk Satuan Pendidikan Dasar dan Menengah. Jakarta. Badan Standar Nasional Pendidikan.

Budiningsih, Asri. 2003. Desain Pesan Pembelajaran. Yogyakarta : FIP Universitas Negeri Yogyakarta

Djajadisastra, Jusuf. 1982. Metode-Metode Mengajar. Bandung: Angkasa.

Gulo, W. 2002. Metode Penelitian. Jakarta: PT. Grasindo

Hopkins, David. 2011. Panduan Guru Penelitian Kelas (A Teacher's Guide To Classroom Research). Yogyakarta : Pustaka Pelajar.

Kartawidjaja, Omi. 1988. Panduan Pengajar Buku Metoda Mengajar Geografi. Jakarta : P2LPTK.

Makmun, Abin Syamsuddin. 2004. Psikologi Kependidikan. Bandung : Remaja Rosdakarya. 
Posamentier, Alfred S. 1990. Teaching Secondary School Mathematics : Techniques And Enrichment Unit. Columbus : Merrill

Saidihardjo. 2005. Paradigma Baru Pembelajaran. Jakarta : Kencana.

Sri Rumini, dkk. 1995. Psikologi Pendidikan. Yogyakarta : Unit Percetakan dan Penerbitan (UPP) UNY.

Sudijono, Anas, 2005. Pengantar Evaluasi Pendidikan. Jakarta : Raja Grafindo Persada.

Sudjana, Nana, 1989. Teknologi Pendidikan. Bandung : Sinar Baru.

Sudjana, Nana, 2005. Penilaian Hasil Proses Belajar Mengajar. Bandung : Remaja Rosdakarya.

Sumaatmadja, Nursid. 1984. Metodologi Pengajaran Ilmu Pengetahuan Sosial (IPS). Bandung : Alumni.

Sumaatmadja, Nursid. 2001. Metodologi Pengajaran Geografi. Jakarta : Bumi Aksara. 